\title{
AN OPEN GOVERNMENT IMPLEMENTATION MODEL FOR MIGRATION MANAGEMENT: THE CASE OF RUSSIA
}

\author{
Valeriy A. Achkasov \\ Doctor of Philosophy, Professor of STSU, Head of the Department of Ethnopolitology \\ Address: Saint Petersburg State University 1/3 Smolnyi Str., entrance 7, \\ St. Petersburg 191060, Russian Federation. E-mail: val-achkasov@yandex.ru
}

\section{Marya S. Rozanova}

Ph.D., Professor of RSHU; Head of the Center for Civil, Social, Scientific, and Cultural Initiatives "STRATEGIA"

Address: Russian State Hydrometeorological University. 98 Malookhtinsky Prospect, St. Petersburg 195196, Russian Federation. Email: marya.rozanova@yahoo.com

\begin{abstract}
Large-scale migration against the full spectrum of demographic, economic and socio-cultural challenges in Russia highlight the necessity for further reconsideration of the deeply rooted vestiges of traditional models of public administration based on Weber's theory of rational bureaucracy. Authors argue that the newly forming concept of Good Governance through the implementation of the core principles of the Open Government model - the inclusion principle and the principle of information transparency in government - can be an adequate response to the complexity of the changing reality, i.e., Russia’s current and future challenges.

The authors present an inclusive migration concept - Immigration as Affiliation (H. Motomura) - as complementing the Good Governance concept in the sphere of government migration management. To describe existing effective mechanisms of and existing barriers to this migration concept implementation, sequential analysis is provided both for the sphere of public administration, and public service in Russia.
\end{abstract}

Keywords: migration management; migrants; public administration; public service; Open Government Model; Good Governance, Russia.

Citation: Achkasov, V.A. \& Rozanova, M.S. (2016). An Open Government Implementation Model for Migration Management: The Case of Russia. Public Administration Issues, no 5 (Special Issue, electronic edition), pp. 77-91 (in English).

\section{Introduction}

The reality of a new Russia, highlighted by a demographic shift and intensified large-scale labor migration, requires a reassessment and revision of basic principles and approaches in migration public management, as well as new forms of state regulation for the increasing complexity of the social reality, and collaboration with new social groups/actors (Obolonsky, 2011). 
Transnational migration is gradually becoming an integral component of the socio-economic and political spheres of Russia against the background of an increasingly ageing population, a projected significant reduction in the working age population, and increasing labor shortages. It is thus quite clear that Russia's migration policy is aimed, above all, at comprehensively and consistently addressing three main objectives in economic, demographic, and socio-cultural spheres:

- firstly, the necessity to constantly overcome the growing labor shortages in all sectors of the national economy, by taking effective measures to implement the transition from unregulated labor migration towards replacement immigration - secondly, a pressing need to mitigate the depopulation processes in a number of regions, as well as in the country as a whole, since by 2025 the population of Russia is going to shrink by at least 10-15 million people (medium scenario of the population projection)

- thirdly, the necessity of facilitating labor immigrants comprehensive integration into both institutional and socio-cultural environments.

As the historical migration experience of Western European countries, which modern Russia predominantly follows, has shown, achievement of the above mentioned objectives depends on a gradual reform of the system of public migration management, as well as changing the Russian migration legislation conceptual frameworks.

This migration reform requires the inevitable transition in a medium- and long-term perspective from the rigid concept of Immigration as Contract towards the more flexible and inclusive modern migration concept of Immigration as Affiliation (Motomura, 2006) as is inherent to new immigration countries. The former concept correlates with Weber's theory of rational bureaucracy (Sager \& Rosser, 2009; Gale \& Hummel, 2003) and clearly defines and limits the agents of public management and objects of managing; the latter is associated with the new emerging state-public governance concept of Good Governance (GG) through the implementation of the core principles of the Open Government model (OG).

The Immigration as Contract concept has at its core one simple demand that labor migrants are being forced to accept and obey: "play by our rules or leave". It is "based on the sense that fairness and justice for lawful immigrants does not require us to treat them as the equals of citizens" (Moromura, 2006, p. 10) and, the state is unilaterally entitled to make any decisions towards migrants as objects of managing without considering the interests of the latter and thus allowing a wide margin of latent and open conflicts in the future.

The most preferred alternative for Russia, on the premise that in the future it will inevitably become a new immigration country, is the phased implementation of the modern and flexible migration concept - Immigration as Affiliation. Correlating with the GG model, this migration concept focuses on the principle of inclusion (participation) in the process of gradual integration of labor migrants/immigrants (and most importantly - their children) in public and political relations as they are getting permanent employment, giving birth to children, obtaining the citizenship of a receiving country, and strengthening their social ties. In this process immigrants are gradually transforming "from outsiders to quasi citizens" (Rodriguez, 2008, p. 1113). In Russia, the complexity of the transition towards this modern model 
of public migration management is due to the country lacking a genuine development strategy as well as articulated clear objectives in the migration sector ${ }^{1}$, which inevitably negatively affects the quality of governance (Lee, Rainey \& Chun, 2009). Another negative side-effect is related to the absolute predominance of anti-immigrant rhetoric (often of populist and pro-nationalist orientation) in the public/political sphere presented by so-called "modernizers", "conservative statists" and "cultural

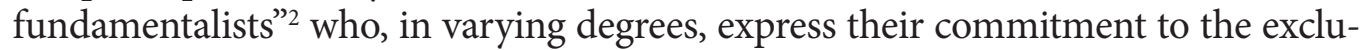
sive migration model of the Persian Gulf states (although the applicability of this model for the Russian context is highly questionable).

As the past migration experiences of Western European countries (which modern Russia is following) have demonstrated, the risk of the long-term use of state discriminatory practices and exclusive Weber theory's approaches in respect to "temporary" labor migrants is that sooner or later a growing latent conflict of interests becomes an open confrontation between sides. Such conflicts in the migration sphere are particularly acute and multilayered as the conflict sides often differentiated along the markers of ethnicity, religion, and legal status.

In this article the authors argue that for Russia the carefully calibrated introduction of the modern migration concept of Immigration as Affiliation based on the principles of OG will provide a more stable and equitable balance of interests between different groups and reduce the risk of instability (Barabashev, 2013; Manning \& Parison, 2003; Bevir, Rhodes \& Weller, 2003) in the economic and socio-cultural spheres.

\section{The Core Principles of the OG Model in Migration Management}

Despite the fact that Russia has not joined the Open Government Partnership platform yet, some significant steps of great importance towards the modernization of the public administration system were made in 2012 by launching the OG project in Russia". The goal of this project is the revision of the principles of "traditional" public administration with its coordinate system of "agents of public management - (vs.) objects of managing" in favor of public service and civil society increasing its openness and the revision of the principles of the capacity-building of civil servants (Borshchevskiy, 2014, p. 77).

In relation to the migration administration in Russia, the transition to the concept of Immigration as Affiliation is closely linked to the implementation of the

\footnotetext{
1 In 2012 President V. Putin approved the State Migration Policy Concept of the Russian Federation through to 2025 , but it is largely lacking in strategy and practical relevance.

2 In the terminology of V. Malakhov, in Russia a public political discourse on immigration is "monopolized" and divided among the following players:

- "modernizers" focus on the negative impact of a large contingent of low-skilled migrant workers as their labor hinders economic modernization in Russian;

- "conservative statists" emphasize connecting migration with national security threats (using the broadest possible interpretation of the term "national security");

- "cultural fundamentalists" appeal to "cultural purity" preservation (in terms of so-called "spiritual security") of the Russian society and consider migrants - bearers of an alien culture - as a permanent substantial threat (Malakhov, 2016, p. 16-17).

3 Open Government project (2012) in Russia (www.open.gov.ru) is mainly based on the US Open Government Directive (2009) (www.whitehouse.gov/sites/default/files/omb/assets/memoranda_2010/m10-06.pdf).
} 
following principles of modern public administration which are based on the OG model: (1) inclusion (civil society participation), and (2) information transparency.

We are going to analyze the existing institutions and administrative practices that are used to implement these two principles in the sphere of governance of migration policy and correlate the latter with the current situation in labor migration/migration processes in Russia.

\section{The inclusion principle}

Under the conceptual framework of GG the basis of this principle implementation is the "so-called "neoliberal solution", which is extending the notion of the state to include other organizations (Schultz, 2014)" (Barabashev, 2016, p. 178). As a result, a "monopolized assignment and performance of functions [by the state in the past - authors] is becoming replaced by a collaborative system ${ }^{4}$ of public actors in networks of joint efforts of governmental civil society actions (Collaboration Network) (Osborne, Radnor \& Strokosch, 2016)" (Barabashev, 2016, p. 178).

In relation to migration management in Russia, at the moment it can be noted that the basis for the functioning of a new system of collaborative governance that provides cooperation between public and civil society actors (though not on the principle of separation of powers yet) has been established, as well as institutionalized mechanisms of representation of the various social groups' interests - mainly citizens, but also lawful permanent residents and foreign nationals.

Since the rights and legitimate interests of the labor migrants are not presented by any political party in Russia, the realization of the principle of inclusion is of tremendous importance. This principle can be implemented - to varying degrees - by the following representative and consultative/advisory bodies:

- The Public Chamber of the Russian Federation (www.oprf.ru) and regional public chambers as a special mechanism that promotes articulation, aggregation of social groups' interests, and representation of the latter.

- Public/Expert Councils (consultative and advisory bodies) affiliated with relevant public authority bodies as mechanisms for conveying the considered views/expertise of certain social/professional groups with the possibility of potentially reconciling them in the decision-making process 5 .

In implementing the principle of inclusion, each of the above mentioned institutions experiences certain issues associated with the alignment of the mechanisms of formation/functioning of representative, advisory/consultative bodies in correlation with the realities and specific features of labor migration processes in Russia. Among these issues are the following:

1) Regarding the potential opportunities offered by the Public Chamber of the Russian Federation and regional public chambers for representation of the migrant workers/communities' interests, it is important to note that the following issues remain unresolved:

\footnotetext{
See also: Collaborative Governance (Ansell \& Gash, 2008).

Councils on Interethnic Relations and Migration Policy affiliated with the Committees/Ministries in constituent territories of the Russian Federation; Expert Council of the Federal Migration Service (until 2016); Presidential Council for Interethnic Relations, and others.
} 
(a) The legitimacy of the heterogeneous contingent representation (migrant's groups are differentiated by country of origin, length of stay and current status in Russia, professional affiliation; different life strategies of the migrants themselves at the personal level, adaptive skills, etc.)

(b) The mechanism of the delegation of a right of representation and promotion of the interests of migrant groups (primarily, the criteria of candidates electivity).

The Legitimacy of Heterogeneous Contingent Representation

In theory, the representation of such a significant group as migrant workers/ migrants in contemporary Russia and conveyance of its considered views/interests to the decision makers, as well as the gradual inclusion of this group into socioeconomic and political processes as new actors, are important tasks for any progressive comprehensive cooptation of this contingent (at least, part of it) into the socio-economic and political sphere of the receiving country.

It should be noted that in Russia the high heterogeneity of the migrant group a factor which is not sufficiently taken into account - can be a barrier to achieving these tasks. For example, sociological studies in St. Petersburg showed that any migrant community (often called "ethnic diaspora") consists of various social environments that are relatively isolated and barely interact with each other. In particular, taking the example of Azerbaijani migrant community, rigid boundaries between at least several subgroups were discovered. The first subgroup consists of migrants/immigrants (residents of Azerbaijani origin), well integrated and who have achieved a certain economic well-being in various spheres in St. Petersburg. During their spare time they "have a privilege to be "Azeris"... As a rule, they act as leaders of ethno-cultural autonomies. Some of them have made ethnicity a hobby, others - a profession. They claim to represent the interests of "all Azerbaijanis of St. Petersburg" (Panchenkov, 2008, p. 169) and to be the key intermediaries between "Diaspora" and regional authorities.

Meanwhile, the second heterogeneous subgroup (much larger than the first one in numbers) - consists of the new incoming economic migrants and "temporary" labor migrants. The boundary between these sub-subgroup communities is not of an ethnic dimension, but based on several interconnected criteria: length of stay in the city, degree of integration, social and legal status, lifestyles and so on" (Panchenkov, 2008, p. 169-170). Typically, the aggregation of interests of this important sub-subgroup remains problematic as it is related to candidates' electivity criteria.

The Mechanism of the Delegation of a Right of Representation

According to The Federal Law of the Russian Federation from 4 April 2005, N 32-FZ "About the Public Chamber of the Russian Federation" (Current state on 28.11.2015), Article 7, an important criterion for a candidate's election to the Chamber is their legal status - citizenship of the Russian Federation. Under The Federal Law of the Russian Federation from 23 June 2016, N 183-FZ "About General Principles of the Organization and Activities of Public Chambers of Subjects of the Russian Federation," in order to get elected to the regional public chamber the candidate should be delegated by an non-profit/NGO organization. Also, besides citizenship of the Russian Federation, the candidate should also be a resident on the territory of the subject and have worked in the sphere of his/her representa- 
tion and in the protection of the rights and legitimate interests of professional and social groups for at least three years.

This criterion for electivity allows to one to constitute the right of the first smaller sub-group (see above) representatives - as a rule, the heads of national-cultural autonomies - to speak on behalf of every single person belonging to (or associating with) a certain "nationality" (ethnicity). On one hand, the lack of Russian citizenship puts considerable groups of labor migrants/migrants in the position of outsiders, whose interests may not be represented at the public level. On the other hand, the difficult procedure of obtaining Russian citizenship forces migrants to rethink their life strategies in favor of temporary stays. Thus, since the migration concept of Immigration as Contract dominates in Russia, many labor migrants/migrants often do not think about the legalization of their status, considering it to be a waste of time and money, and describing naturalization/legalization as a vain attempt to address an issue that is not going to bring them any dividends.

Sociological surveys on labor migrants/migrants of different origins show that about $27 \%$ of migrants are willing to stay in Russia for their entire life-time (Mukomel, 2012, p. 254). However, experts express doubts that migrants giving certain direct answers in questionnaires are necessarily going to implement them in reality. Obviously, a particular migrant, depending on many factors may, firstly, have several variable scenarios of his/her future life strategy, actualizing under the certain consequences of one of these; and secondly, they may make adjustments and change these scenarios in the light of the new circumstances. It applies both to those who, according to the questionnaire surveys, "are going stay in Russia," and to those who, at the moment, are not. Time-extended in-depth interviews with labor migrants from Central Asian countries show that they are, most of the time, likely to be in a never-ending search for the best life opportunities and adjusting their plans all the time. It is necessary to also take into account that migrant's behavior, especially of those who are coming from rural areas or small towns of Central Asia, is strongly determined not so much by his/her sole decisions, but as a result of difficult negotiations within the networks that the migrant belongs to. He/she is influenced by the general regulatory requirements (how he/she should behave), as well as the opinions of relatives and friends, and also has to protect the common interests of the family (Abashin, 2016, p. 35).

A more relevant data collection is that which was provided by the World Bank as a result of a survey of Tajik migrants who have stayed in Russia for more than three months. This survey showed that $73 \%$ of migrants prefer a temporary (circular) labor migration, 11\% would like to stay in Russia for up to one year, and only $16 \%$ expressed their wiliness to establish permanent residence in Russia. The survey provided similar results for Kyrgyz migrants ${ }^{6}$.

It has to be pointed out that presently Russia is lacking in the practice of representing migrants' interests in the Public Chamber as an institution for public representation. Russian citizenship as a formal electivity criterion for a Chamber candidate, and in being a main mechanism of the Public Chamber formation, is further exacerbating the gap in representation between the "old-timers" and

See: World Bank, www.worldbank.org/ECA. 
new incoming migrant workers who have not rationalized their life strategy yet. Thus, this criterion is putting these migrant workers in a marginal position, and pushing them beyond the framework of Russian society.

2) Public/Expert Councils (Consultative and Advisory Bodies) Affiliated with Relevant Public Authority Bodies

An impressive legal framework has recently been established for the regulation of the organization and modalities public appraisals and expert deliberations ${ }^{7}$ in preparation for the decisions to be made by the Government. According to experts Y. Kuzminov and A. Zhulin, "consistency of the methodological and regulatory framework of the Open Government in Russia has no world analogues and it is recognized by many foreign partners"(Kuzminov \& Zhulin, 2016, p. 4).

Public and Expert Councils (consultative/advisory bodies) affiliated with the relevant Federal and regional government executive bodies are important institutions that symbolize a progressive movement of the public administration in Russia towards the type found in advanced democracies. At the same time the practice of organization and functioning of those councils specializing on migration and migrant integration issues does not always provide an adequate response to the challenges of modern Russian reality.

We can allocate the following commonly used applied administrative practices that can have a negative impact on council performance and make them less efficient:

- The use of selective, non-transparent mechanisms of council formation;

- Admittance (by invitation) as members of councils of so-called 'leaders' of ethno-cultural associations (hereinafter - EC association ${ }^{8}$ ) and ethno-cultural autonomies (hereinafter - EC autonomy $\left.{ }^{9}\right)^{10}$;

The Presidential Decree of the Russian Federation from 2 September 2012, N 167 "About the public discussion of draft Federal constitutional laws and Federal laws;" The Order of the Government of the Russian Federation from 1 September 2012, N 877 "About approval of structure of regulatory legal acts and other documents, including program, developed by federal executive bodies which cannot be accepted without preliminary discussion at meetings of public councils in case of these federal executive bodies" (Current state on 15.06.2013); The Order of the Government of the Russian Federation from 25 August 2012, N 851 "About the procedure for disclosure by Federal Executive bodies the information on preparation of projects of normative legal acts and results of public discussion" (Current state on 01.04.2016); The Presidential Decree of the Russian Federation from 4 August 2006, N 842 "About the order of formation of public councils at the federal ministries, federal services and federal agencies, management of which activity is performed by the President of the Russian Federation, at the federal services and federal agencies subordinated to these federal ministries" (Current state on 23.05.2013); Federal Law of April 4, 2005 N 32-FZ "About Civic Chamber of the Russian Federation."

8 The mission of EC associations is to establish communication between people of the same ethnicity, language and culture, to preserve and promote ethnic culture, as well as to preserve a native language and ethnic identity.

9 Under the Federal Law of 17 June 1996, N 74-FZ "About Etho-Cultural Autonomy", EC autonomy is comprised of Russian citizens who identify themselves with a certain ethnic group that has a status of ethnic minority group that is corresponding with a certain territory. The EC autonomy mission is a preservation of language, ethnic culture, ethnic identity, and education.

10 According to Vasiliy Filippov, often in practice, EC associations/autonomies provide a "façade" by showing co-optation and demonstrating that migrants groups are obtaining recognition of their cultural rights and legitimate interests by public authorities. Majority of EC associations/autonomies in Russia are focused on competition for the public grants for mass cultural events (the organization of the traditional folk holidays or folk concerts) and for other material benefits. Many "ethnic leaders" are using the status of the "ethnic leaders" to become government officials at the relevant "ethno-cultural agencies" (Filippov, 2001, p. 190). 
- Admittance (by invitation) of representatives of often non-core and "chosen few" institutions of higher education, quasi-experts and pervasive practice of non-admittance of the migrant/immigrant target groups' representatives; - Widespread lack of systematic work of the councils (their effectiveness and work on a regular basis or formal work 'for show' largely depends on the political will of the head of the relevant administrative body).

Furthermore, a special problem concerns the legitimacy of the representation of migrant groups by the 'leaders' of EC associations/autonomies. Valeriy Tishkov points out the problem of migrant/ethnic groups' heterogeneity and the varying degrees of representation of such groups by EC associations/autonomies: “...often a group of people united in a ethno-cultural autonomy, is trying to represent the interests of all the people. Meanwhile, in such organizations it is difficult to envisage the democratic election procedures. Therefore, what theses ethno-cultural autonomy organizations are talking and writing about cannot be shared by with thousands and tens of thousands of those who belong to the same nation. Due to this fact, situations fraught with serious consequences are often taking place..." (Tishkov, 2008, p. 16). Officially registered EC associations/ autonomies and ethnic organizations of immigrants from former Soviet states are characterized by their non-transparent way of functioning and the weak engagement of newly arrived migrants. Many heads of EC associations/autonomies are using their status as a tool to achieve personal/ narrow group (clan, family, etc.) economic, political and other goals. In turn, this produces a replication of such negative phenomena as clientelism and corruption. Thus, the representative of the Association of Assyrians in Moscow, R. Bidjamov, describes the situation as follows: "The legitimacy of the ethno-cultural organizations is a very vexing question for all of us. It is no secret that most of them are in reality types of interest groups or clubs; they are quasi organizations that do not have strong links with the ethnic environment and are often headed by unprofessional, incompetent, ambitious leaders who are profoundly alien to democratic traditions" (Filippov, 2008, p. 7-8). Often the leaders and activists of the EC associations/autonomies are carrying out the role of intermediary between migrants and local employers, acting as ethnic entrepreneurs and exacerbating the "shadow" market economy of foreign labor in Russia. It was they who "ensured a continuous influx of laborforce from their countries and reserved job quotas for migrants under their own mediation business, turning the latter into a commodity; "took upon themselves" all the "hassles "for the legalization of the newly arrived migrants; and often sold them fake permits and medical insurances" (Yushkovskaya, 2014, p. 3), thus aggravating the situation with migrants who had been already rendered powerless.

Thus, in modern Russia EC associations/autonomies do not fit the criteria of classic civic associations which are based on principles of self-organizing, democratic procedures, non-hierarchical system of development and decisionmaking process, relative autonomy from the state, etc. The functional specificity of the Russian EC associations/autonomies affects the councils' work performance. A special feature is that "ethnic entrepreneurs, ethnically biased researchers, and government officials are becoming the main experts, although their selfinterests lie $<\ldots>$ in preserving local and in particular ethnic identities" (Shabaev \& Sadokhin, 2014). Often this leads to a contradiction with the mission of these 
councils to provide objective expertise on interethnic relations together with the harmonization of relations between different social groups (especially between newly arrived migrants and host society members), and to contribute to the socio-cultural adaptation and comprehensive integration of labor migrants into Russian society.

At the same time, the potential of the few socially-oriented and human rights organizations that perform important functions for labor migrant groups' interests and representation, as well as the protection of migrants basic rights and legitimate interests, virtually remains unclaimed. The range of these organizations activities is very limited; they lack broad social support among migrants themselves $^{11}$. For the most part, they are deprived of the opportunity to convey their considered views to the general public and policy makers and thus these organizations are excluded from the public and political domain. Their activities are involuntarily directed, primarily, not towards the resolution of accumulated systemic problems in the sphere of migration management, but rather towards providing social and legal assistance and support to migrants on an individual basis.

\section{The Principle of Information Transparency in Government}

Providing the general public with objective and comprehensive information about both the current state of migration processes, and appropriate measures in migration management is of tremendous importance in the light of the high levels of widespread xenophobia and migrant-phobia widespread the general population in Russian. Incomplete, inconsistent and unreliable data on migration can have a direct impact on social relations and lead to their destabilization.

Despite the legal regulations in Russia that oblige the authorities to inform the population about the state of affairs in their respective field of activities/responsibilities, "the conducted expert analysis indicates the lack of a unified State policy in respect of the information provided by government information resources, $\langle\ldots\rangle$ led to the administrative barriers appearance in obtaining information and significantly reduced access to available information" (Dmitrieva \& Styrin, 2014). In general, most websites of relevant government bodies formally comply with legal requirements, but their content does not meet the necessary conditions

\footnotetext{
11 On the one hand, an overall low level of organizational engagement and participation in the political sphere among migrants/immigrants; unwillingness to defend their rights and legitimate interests, including the simplification and liberalization of migration laws to work, go to school for migrant children (and continuously attend classes), or apply for permanent status in Russia, - are related to migrant/ immigrant political and legal cultures they belong to as they come mostly from developing countries with underdeveloped democratic traditions and institutions.

- On the other hand, so-called "sovereign democracy" established in Russia and aggravated by corruption in the relevant agencies confront any migrant with a typical choice - either to stay quiet or not leave the workspace/temporary home to have an opportunity to work, or to be active and finally face high risk of deportation and little chance of return.

- Typical for many migrants unwillingness to defend their own socio-economic rights is due to the fact that before going to Russia they psychologically adjust, i.e. prepare themselves for deprivation, temporary heavy and non-prestigious work. And the lack of interest in the comprehensive social migrant integration in Russian society is due to, on the one hand, high level of xenophobia/migrant-phobia among receiving society members and the complexity of migrants embedding in social relations, and the impossibility of obtaining social benefits (unlike in the EU), - on the other hand.
} 
of completeness, relevance, validity, and understandability of information for the users. That is why, according to sociological surveys, "65 percent of the daily Internet audience use social media and blogs to find objective information" (Kuzminov \& Zhulin, 2016). Taking into account the specificity and growing politicization of migration-related topics, the lack of objective information may negatively impact the quality of modern governance and undermine the population's confidence in Government institutions, as well as largely affect public opinion and social relations in general.

\section{Formation of a Professional Cadre for Public Service in the Sphere of Migration Management}

Professional training for government officials is one of the key tasks of the OG principles' implementation, based on the way the realization of the modern concept of GG is in practice. From 2002 to the present there has been a consistent trend both at Federal and regional levels in Russia for the gradual targeted replacement of "civilians" at key public service vacancies by the so-called "siloviki" (candidates who served in security, militia, and military agencies). This is mainly due to the fact that current competitive selection and hiring procedures commonly used in the system of government service are not competency-based recruitment processes and are not based on the adversarial principle and openness, and thus are of "subjective and formal character ... that brings to civil service candidates with the worst professional competencies. ... " (Borshchevskiy, 2014, p. 73).

According to the expert Georgiy Borshchevskiy, among the specific features of administrative practices in Russia which make it extremely difficult to implement the OG principles in practice and to enable the government administration to function effectively, are the following factors: the recruitment by pulling strings and on the basis of personal fidelity (42.4\%), lack of priorities in personnel policies $(34.1 \%)$, and underestimation of the role of professional competencies in selection and recruitment process (23.5\%) (Borshchevskiy, 2011).

As a result, a number of government bodies regulating and managing migration processes (in particular, the Directorate for Migration Affairs of the Ministry of Internal Affairs and the Federal Agency for Ethnic Affairs) clearly show common features of the civil service in modern Russia:

- "militarization" of the public administration" ${ }^{12}$ (more than half of the former representatives of security and law enforcement agencies, former officers

\footnotetext{
12 For instance, Olga Kirillova, Head of the Directorate for Migration Affairs of the Ministry of Internal Affairs, is a Police Colonel; Igor Barinov, a Head of the Federal Agency for Ethnic Affairs, a Colonel, served as a head of the FSB regional squad "ALFA" (before being elected Deputy of the State Duma (parliament of the Russian Federation) in 2003); Mikhail Ipatov, a Deputy Director of the Federal Agency for Ethnic Affairs has worked most of his career for the military services; Police Major-General Oleg Makhno, a Head of the St. Petersburg Committee on Inter-Ethnic Relations and Implementation of Migration Policy, served most of his carreer under the Ministry of Internal Affairs of the Russian Federation before being appointed by the Lieutenant-General Georgy Poltavchenko, current Governor of St. Petersburg who most of his career served in KGB and police agencies; Vadim Y. Okrushko, a Deputy Director of the St. Petersburg Committee on Inter-Ethnic Relations and Implementation of Migration Policy, is a Police Colonel and most of his career served in police agencies.
} 
of the $\mathrm{KGB} / \mathrm{FSB}^{13}$, in particular, are in leadership decision-making positions) (Kryshtanovskaya, 2006; 2015)

- general "deintellectualization" of political and executive elites (Kryshtanovskaya, 2002, p. 161;2015) as a result of the ongoing decline in the educational levels of its representatives since $2002^{14}$ and the common practice not to hire (not to invite) specialists with professional competences in a particular occupational area of public administration

- noncompliance with principles of public accountability and information transparency, to a greater or lesser extent ${ }^{15}$.

Nowadays in Russia, public migration agencies, in essence, serve as the "migration police" 16 . This is rooted in the specific public management/leadership style related to the previous professional experience of most public senior executives and a number of staff members who previously served primarily in the security services, and thus lack appropriate competencies/training/experience in such a challenging segment of public governance as migration/immigration management.

According to an expert review by G. Borshchevskiy on the OG project in Russia, to correct these negative trends in public service in Russia, the following basic steps in the sphere of personnel policies are required:

- to introduce mandatory selection procedures for public senior executives, and not for junior staff only as is the case at present

- "to bring professional post requirements for the civil service positions into line with relevant professional standards" (Borshchevskiy, 2014, p. 77).

In times of increasing complexity of migration processes, the lack of civil servants (especially in senior positions) who have obtained professional training and experience in the relevant field of governance to some extent may be one of the main factors causing the so-called crisis of modern state governance "the inability of States to cope with increasing number of challenges of innovative development, speed, complexity, and unpredictability of changes (Obolonsky, 2014, p. 145-146), and to create flexible management tools..." (Barabashev, 2016, p. 166).

According to Alexey Barabashev, expert on crises of state governance and public administration processes, in Russia at the moment the following precursors of this crisis can be found in state migration management:

- "mechanisms of administrative control ... are inadequate to the scale and depth of the problems"

- management solutions are "outdated, costly and corrupt", and do not reflect "the complexity and new phenomena in social life." (Barabashev, 2016, p. 166).

\footnotetext{
13 It is indicative and symptomatic that in 2016 the Federal Migration Service was disbanded, and became a part of the Ministry of Internal Affairs of the Russian Federation.

${ }_{14}$ As a result, civil servants' career advancement has no correlation with their education/professional training profile (Borshchevskiy, 2014, p. 75), and the latter loses its meaning.

15 An exemplary case is the web-site of the St. Petersburg Committee on Inter-Ethnic Relations and Implementation of Migration Policy (www.gov.spb.ru/gov/otrasl/kmormp/).

16 St. Petersburg Committee on Inter-Ethnic Relations and Implementation of Migration Policy is a good example in this regard (Rozanova, 2016).
} 


\section{Conclusion}

The current stage of state migration management can be described as transitional, which combines an eclectic conjunction of Weber's theory of rational bureaucracy together with selective implementation of the OG principles based on the new concept of GG.

It is highly important to note that in 2012 the Russian government, together with experts from the community, laid the foundations for the migration concept Immigration as Affiliation, practical implementation of which requires the systematic introduction of the respective principles of the OG model in the framework of the developing flagship concept of GG. Analysis of the practical experience of the introduction of GG, including through the principles of OG, shows that the problems in its implementation include the lack of goal-setting system, inefficient quality of education and training for public servants, and the closeness of the group of participants in the partnership between Government authorities and public/civil society associations:

- Under current conditions of intensification and complexity of migration processes the GG concept formulated as "a network of interaction between the State and citizens where citizens [highlighted by the authors] participate in managerial decision-making processes, and their organizations and associations are presented in the system of State administration" (Barabashev, 2016, p. 171) does not fully meet the challenges of the new reality in the sphere of migration management. The concept omits from "civil society" labor migrants and most "potential citizens" ("quasi-citizens" - in terms of $\mathrm{H}$. Motomura), who are in the "transition" stage by becoming increasingly active participants in economic, social and political processes in host countries. ${ }^{17}$ Such an artificial separation between citizens and non-citizens in regard to migration is in conflict with the basic principle of OG, namely, the principle of inclusion.

- A deficit of civil servants (especially in senior positions) who have high levels of education, advanced professional training and practical experience in the relevant field of migration management may lead to incoherent and sometimes detrimental actions, and aggravate the so-called crisis of modern state governance.

- Lack of any State goal-setting system/National Strategy is a factor that has a negative impact on the quality of State governance in general. The absence of a vector of the country's strategic development in the sphere of migration (either on the way to new immigration countries with inclusive public management practices, or on the way to Persian Gulf countries with their rigid exclusive approaches and practices) will prolong a situation of uncertainty, sooner or later unleashing demographic and socio-economic instability.

\footnotetext{
17 The (self) segregation of migrant/immigrant communities in the past in Western Europe (particularly, in Germany) that led to instability in social relations and forced the decision-makers to reconsider the principles of interaction with minorities presented by migrants/immigrants. The current political move from the migrant exclusion approach towards concept on comprehensive migrant integration is based on the OG concept that facilitates immigrant cooptation and larger participation in governance/decision-making process.
} 


\section{REFERENCES}

1. Abashin, S.N. (2016). Transnational Migration in Russia and the Potential for Integration. In M. Rozanova (ed.). Labor Migration and Migrant Integration Policy in Germany and Russia. St. Petersburg: Saint Petersburg State University; ScythiaPrint, pp. 33-46.

2. Ansell, C. \& Gash, A. (2008). Collaborative Governance in Theory and Practice. Journal of Public Administration Research and Theory, vol. 18, no 4, pp. 543-571.

3. Barabashev, A.G. (2013). Evolyutsiya Gosudarstvennoi Sluzhbyi Rossii: Itogi Desyatiletiya (2000-2010) [The Evolution of Civil Service in Russia: Results of Decade (2000-2010)]. Moscow: HSE.

4. Barabashev, A.G. (2016). Krizis Gosudarstvennogo Upravleniya i Ego Vliyanie na Osnovnyie Administrativnyie Paradigmyi Gosudarstva i Byurokratii [Crisis of State Governance and its Influence on Basic Administrative Paradigms of State and Bureaucracy]. Public Administration Issues, no 3, pp. 163-194 (in Russian).

5. Bevir, M.M., Rhodes, R.W., \& Weller, P.P. (2003). Traditions of Governance: Interpreting the Changing Role of the Public Sector. Public Administration, vol. 81, no 1, pp. 1-17.

6. Borshchevskiy, G.A. (2011). Professionalno-Lichnostnyie Kachestva Rabotnikov Organov Ispolnitelnoi Vlasti g. Moskvy. Otchet Sotsiologicheskogo Issledovaniya [Professional and Personal Qualities of Employees of Executive Authorities in Moscow. Report of Sociological Research]. Moscow: MGUU Pravitelstva Moskvyi.

7. Borshchevskiy, G.A. (2014). Reformirovanie Gosudarstvennoy Sluzhby V Rossii: Promezhutochnyie Itogi [Civil Service Reform in Russia: Interim Results and Prospects]. Public Administration Issues, 2, pp. 65-88 (in Russian).

8. Dmitrieva, N.E. \& Styrin, E.M. (2014). Otkryitoe Gosudarstvennoe Upravlenie: Zadachi i Perspektivy [Open Government: Challenges and Prospects]. Public Administration Issues, no 1, pp. 127-148.

9. Filippov, V.R. (2001). Krizis Etnicheskogo Federalizma v Rossii [Crisis of Ethnic Federalism in Russia]. In: V. Filippov (ed.). Regions and Regionalism in Western Countries and Russia. Moscow: IVI RAN, pp. 183-192.

10. Filippov, V.R. (ed.) (2008). Etnicheskie Protsessy v Stolichnom Megapolise [Ethnic Processes in the Capital]. Moscow: IVI RAN.

11. Gale, S.A. \& Hummel, R.P. (2003). A Debt Unpaid-Reinterpreting Max Weber on Bureaucracy. Administrative Theory \& Praxis, vol. 25, no 3, pp. 409-418.

12. Kuzminov Y.I. \& Zhulin, A.B. (eds.) (2016). Presentation of the Report on Perspectives of the Administrative Reform at the XVII April International Academic Conference on Economic and Social Development is Russia (Moscow, HSE, April, 19-22, 2016). Available: https://www.hse.ru/science/reports (accessed: 23 August, 2016). 
13. Kryshtanovskaya, O. (2002). Rezhim Putina: Liberalnaya Militokratiya? [Putin's Regime: Liberal Militocracy?]. Pro et Contra, vol. 7, no 4, pp. 158-180.

14. Kryshtanovskaya, O. (2006). Militokratiya i Demokratiya v Rossii XXI Veka [Militocracy and Democracy in Russia in $21^{\text {st }}$ Century]. Upravlencheskoe Konsultirovanie [Management Consulting], 2, pp. 24-41.

15. Kryshtanovskaya, O. (2015). Presentation of the Report on Cooperation Between Russian and Ukrainian Elites at the Kennan Alumni Conference on the Role of Public Intellectuals in Russian-Ukrainian and Ukrainian-Russian Dialogue (Kyiv, Ukraine, May 22-24, 2015).

16. Lee, J.W., Rainey, H.G. \& Chun, Y.H. (2009). Of Politics and Purpose: Political Salience and Goal Ambiguity of US Federal Agencies. Public Administration, vol. 87, no $3,457-484$.

17. Malakhov, V.S. (2016). The Phenomenon of New Immigration Countries: Russia's Case in the European Context. In: M. Rozanova (ed.). Labor Migration and Migrant Integration Policy in Germany and Russia. St. Petersburg: Saint Petersburg State University; Scythia-Print, pp. 11-22.

18. Manning, N., \& Parison, N. (2003). Reforma gosudarstvennogo upravleniya: Mezhdunarodnyiy opyit [Public Administration Reform: International Experience]. Moscow: Ves Mir.

19. Motomura, H. (2006). Americans in Waiting: The Lost Story of Immigration and Citizenship in the United States. Oxford; New York: Oxford University Press.

20. Mukomel, V. (2012). Transformatsiya Trudovoy Migratsii: Sotsialnye Aspekty [Transformation of Labor Migration: Social Aspects]. In: M. Gorshkov (ed.). Rossiya Reformiruyushchayasya [Reforming Russia]. Moscow: Novyy Khronograf, pp. 236-264.

21. Obolonsky, A.V. (2011). Krizis byurokraticheskogo gosudarstva: Reformyi gosudarstvennoy sluzhbyi: mezhdunarodnyiy opyit $i$ rossiyskie realii [The Crisis of Bureaucratic State: Civil Service Reforms: International Experience and Russian Realities]. Moscow: Foundation "Liberal Mission".

22. Obolonsky, A. (2014) Krizis effektivnosti administrativno-byurokraticheskogo gosudarstva i poiski vykhoda: opyt SShA (evolyutsiya teoriii praktiki gosudarstvennogo upravleniya v poslednie desyatiletiya) [The Crisis of Bureaucratic State's Effectiveness and the Search for the Way Out: USA's Experience (The Evolution of Theory and Practice of Public Administration during the Last Decade)]. Public Administration Issues, no 2, pp. 145-170 (in Russian).

23. Osborne, S., Radnor, Z. \& Strokosch, K. (2016). Co-Production and the Co-Creation of Value in Public Services: A Suitable Case for Treatment? Public Management Review, vol. 18, no 5, pp. 639-653.

24. Panchenkov, O.V. (2008). Rol "Etnicheskoy Identichnosti" v Issledovaniyakh Migratsii i Otvetstvennost Sotsialnogo Uchenogo [The Role of "Ethnic Identity" in Migration Studies and the Social Responsibility of the Scientist]. Journal of Sociology and Social Anthropology, no 1, pp. 162-182. 
25. Rodriguez, C.M. (2008). The Citizenship Paradox in a Transnational Age. Michigan Law Review, vol. 106, no 6, pp. 1111-1128.

26. Rozanova, M. (2016). Russia as an Emerging Immigration Country? Changing Approaches to Migrant Integration: From Tolerance to the "Migration Police" (The Case of St. Petersburg). In: M. Rozanova (ed.). Labor Migration and Migrant Integration Policy in Germany and Russia. St. Petersburg: Saint Petersburg State University; Scythia-Print, pp. 29-146.

27. Sager, F. \& Rosser, C. (2009). Weber, Wilson, and Hegel: Theories of Modern Bureaucracy. Public Administration Review, vol. 69, no 6, pp. 1136-1147.

28. Schultz, D. (2014). Ideya “Gosudarstva” v Sovremennoy Teorii Publichnogo Administrirovaniya [The Idea of the "State" in Contemporary Public Administration Theory]. The Bulletin of Peoples' Friendship University of Russia, Public Administration Series, no 1, pp. 90-102.

29. Shabaev, Y.P. \& Sadokhin, A.P. (2014). Lokalnyie Problemy Realizatsii Gosudarstvennoy Natsionalnoy Politiki Rossiyskoy Federatsii [Local Problems of the State National Policy Implementation in the Russian Federation]. POLITEKS, vol. 10, no 1, pp. 5-30.

30. Tishkov, V. (2008). Etnicheskoe i Religioznoe Mnogoobrazie - Osnova Stabilnosti $i$ Razvitiya Rossiyskogo Obshchestva [Ethnic and Religious Variety as the Base for Stability and Development of the Russian Society]. Moscow: Academia.

31. Yushkovskaya, I. (2014). Uvazhaemyi, Kak Stat' Migrantom? [Dear, How to Become a Migrant?]. Sankt-Peterburgskie Vedomosti [St. Petersburg Statements], December, 11, p. 3. 